\title{
COMPARATIVE ANALYSIS OF DEVIL'S TOWN AND BRYCE CANYON GEOSITES BY APPLYING THE MODIFIED GEOSITE ASSESSMENT MODEL (M-GAM)
}

\author{
Vladan Jonić ${ }^{1}$ \\ Received: August 2, 2018 | Accepted: October 24, 2018
}

\begin{abstract}
The main objective of this study is to compare two similar geosites in two countries with different levels of geotourism development, Serbia and USA. The comparative analysis was carried out by applying the M-GAM model for geosite assessment which considers visitor opinion in the assessment process. Our findings indicate that the two analyzed geosites, Devil's Town and Bryce Canyon attract tourists mainly due to their aesthetic values. The comparative analysis also revealed the advantages and disadvantages of the analyzed geosites as well as the areas on which geosite management should focus their attention in the future. Additionally, the paper also emphasizes the main barriers for geotourism development as well as areas which require improvement. These are mainly related to tour guide service, promotional and interpretive activities. These elements are essential in order to further improve the geotourism offer and attract a larger number of visitors.
\end{abstract}

Keywords: geosite assessment, M-GAM, Devil's Town, Bryce Canyon, Serbia

\section{INTRODUCTION}

Serbia is a country rich in geoheritage sites. According to the Inventory of Serbian geoheritage sites there are approximately 650 geological, paleontological, geomorphological, speleological and neotectonic sites. The significance of these geosites is acknowledged by the Institute for Nature Conservation of Serbia which has so far protected approximately 80 geoheritage sites, including the Natural Monument Devil's Town (Djurović and Mijović, 2006).

The concept of geoheritage is linked to the concept of geosites. Geosites are defined as portions of the geosphere that present a particular importance for the comprehension

Department for Postgraduate Studies, Singidunum University, Danijelova 32, 11000 Belgrade, Serbia; vladanjonic1985@gmail.com 
of Earth history, geological or geomorphological objects that have acquired a scientific, cultural/historical, aesthetic and/or social/economic value due to human perception or exploitation (Reynard, 2004). The type of tourism focusing on geosites is known as geotourism. According to a definition given by Thomas Hose (2003), geotourism includes visits to geosites. The geotourism definition has evolved throughout the years and an updated version was given by Hose and Vasiljević in 2012. According to these authors, geotourism is defined as „The provision of interpretative and service facilities for geosites and geomorphosites and their encompassing topography together with their associated in situ and ex situ artifacts, to constituency-build for their conservation by generating appreciation, learning and research by and for current and future generations".

When it comes to geotourism development it is evident that Serbia has potential. However, it is also obvious that Serbia is still far behind countries like the United States of America where geological tourism is much better developed. Geosites in the USA have better developed geotourism infrastructure as well as geosite management. Therefore, the main goal of this paper is to compare two similar geosites, one in Serbia and one in USA by using the M-GAM model and to determine the advantages and disadvantages of the analyzed geosites as well as the areas on which the Devil's Town geosite management should focus their attention if they want to ascertain the same level of recognition and popularity as similar geosites worldwide.

\section{STUDY AREA}

Devil's Town represents a unique geomorphological phenomenon in Serbia. It includes approximately 200 soil pyramids of various shape and size. The oldest are the highest, reaching $15 \mathrm{~m}$ in height. The smaller ones are about two meters high while some are still in the process of formation. Pyramids are from half meter to three meters wide in their base. These distinctive formations are located at steep slopes of two deep, parallel gullies, between 660 and $700 \mathrm{~m}$ a.s.l. and are a result of erosion processes that lasted over a million years during which they evolved and changed while going through different stages of development. They represent volcano-clastic and volcanic rocks. This interesting geosite has been put under protection in 1959 and in 1995 the Government of the Republic of Serbia declared it as a natural monument putting it into the first category of protection.

This geosite is located in southern Serbia at the base of Radan Mountain, within the municipal district of Kuršumlija. It is approximately $290 \mathrm{~km}$ away from Belgrade, $89 \mathrm{~km}$ from Niš and $27 \mathrm{~km}$ from Kuršumlija (Figure 1). Different relief and geology of particular areas led to significant differences in terrain hydrology. Rare water flows in the Toplica ravine result in weak erosion and accumulation rate. Conversely, frequent flows in mountainous regions lead to intensive erosion and carve deeper valleys (Jovanović, 2010).

Bryce Canyon is located in an American national park with the same name in southwestern Utah. The major feature of the park is Bryce Canyon, which despite its name, is not a canyon, but a collection of giant natural amphitheaters along the eastern side of the Paunsaugunt Plateau. Bryce is distinctive due to geological structures called hoodoos, formed by frost weathering and stream erosion of the river and lake bed sedimentary rocks. The red, orange, 


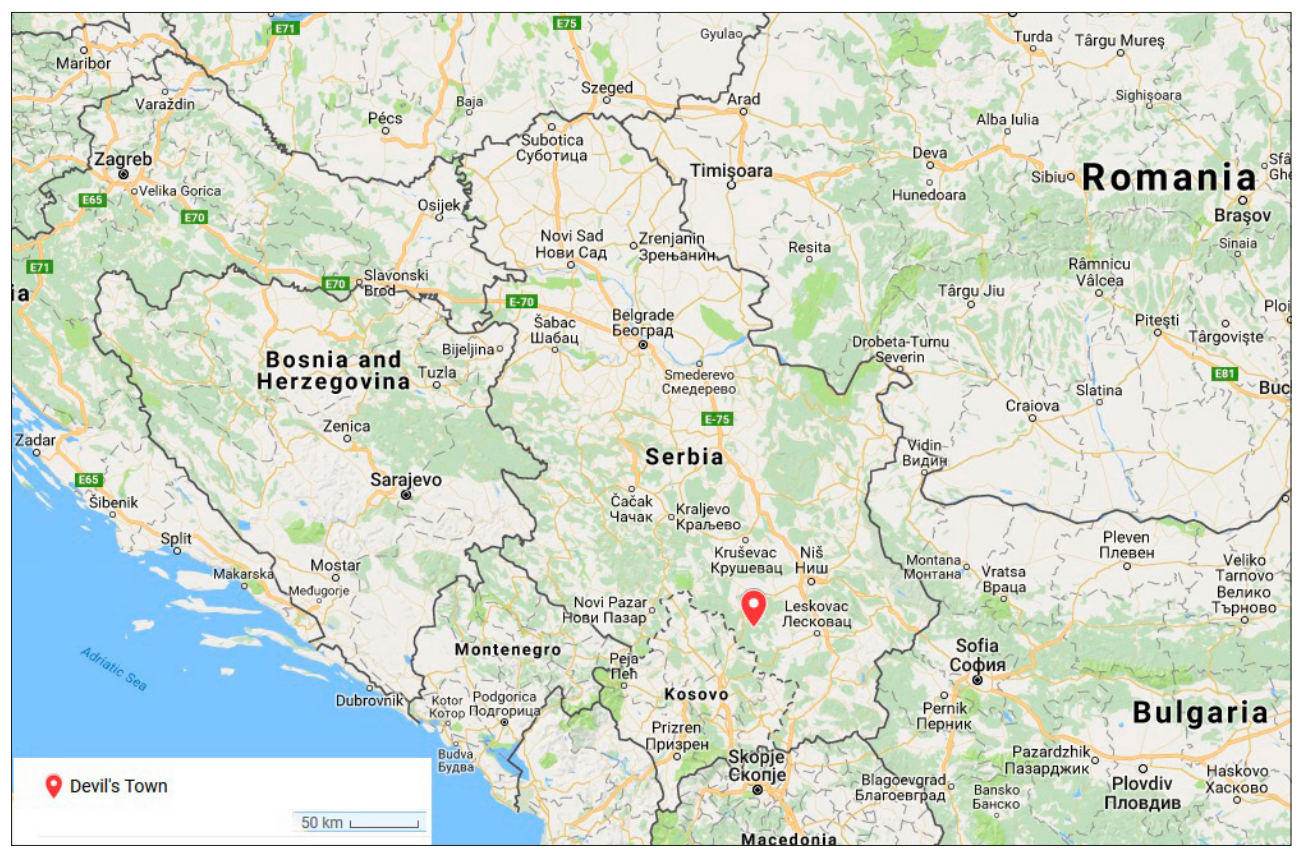

Figure 1. Position of Devil's Town in Serbia

and white colors of the rocks provide spectacular views for park visitors. This geosite was not formed from erosion initiated from a central stream, meaning it technically is not a canyon. Instead headward erosion has excavated large amphitheater-shaped features in the Cenozoic-aged rocks of the Paunsaugunt Plateau. This erosion exposed delicate and colorful pinnacles called hoodoos that are up to $60 \mathrm{~m}$ high (Collison and Poe, 2013).

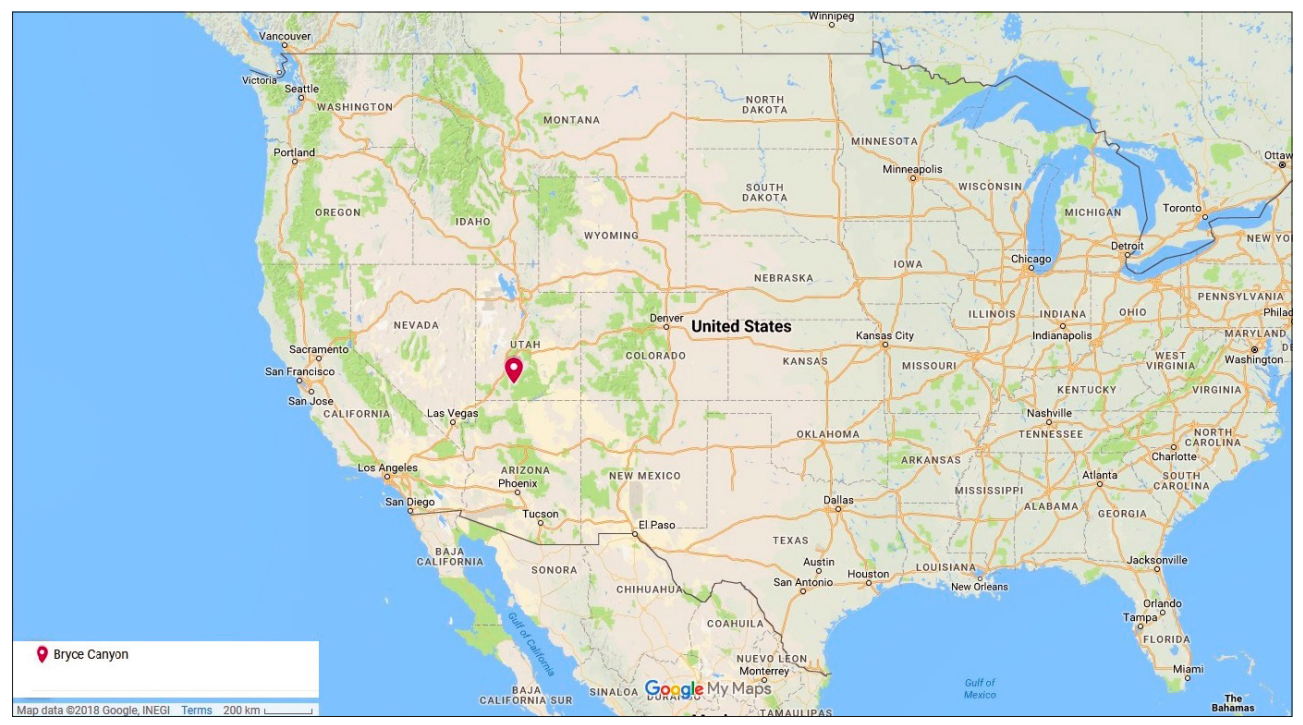

Figure 2. Position of Bryce Canyon in USA 


\section{METHODOLOGY}

The methodology of this study is based upon the 'modified geosite assessment model' (M-GAM), developed by Tomić \& Božić (2014). Previous geosite assessment models contain geosite assessment criteria adjusted towards two main segments of market demand - tourists (Pralong, 2005; Serrano \& González-Trueba, 2005; Hose, 2007; Pereira et al., 2007; Zouros 2007; Reynard et al., 2007; Reynard, 2008; Tomić, 2011) and experts (Hose, 1997; Bruschi \& Cendrero, 2005; Coratza \& Giusti, 2005; Hose, 2008; White \& WakelinKing, 2014). The M-GAM model consists of two key indicators: Main Values and Additional Values, which are further divided into 12 and 15 indicators respectively, each individually marked from 0 to 1 . This division is made due to two general kinds of values: main - that are mostly generated by geosite's natural characteristics; and additional - that are mostly human-induced and generated by modifications for its use by visitors. The Main Values comprise three groups of indicators: scientific/educational (VSE), scenic/aesthetical values (VSA) and protection (VPr) while the Additional Values are divided into two groups of indicators, functional (VFn) and touristic values (VTr). The Main and Additional Values are more detailed presented in table 1. In total sum, there are 12 subindicators of Main Values, and 15 subindicators of Additional Values which are graded from 0 to 1 that define GAM as a simple equation:

$$
G A M=M V+A V \quad[1]
$$

where $M V$ and $A V$ represent symbols for Main and Additional Values. Since Main and Additional Values consist of three or two groups of subindicators, we can derive these two equations:

$$
\begin{gathered}
M V=V S E+V S A+V P r \\
A V=V F n+V T r
\end{gathered}
$$

Now that we know that each group of indicators consists of several subindicators, equations (2) and (3) can be written as follows:

$$
\begin{gathered}
M V=V S E+V S A+V P r \equiv \sum_{i=1}^{12} \operatorname{SIMV} V_{i}, \text { where } 0 \leq \operatorname{SIMV}_{\mathrm{i}} \leq 1 \\
A V=V F n+V T r \equiv \sum_{i=1}^{15} \operatorname{SIA} V_{j}, \text { where } 0 \leq \operatorname{SIAV}_{\mathrm{i}} \leq 1
\end{gathered}
$$

Here, $\operatorname{SIMV}_{i}$ and $\operatorname{SIAVj}$ represent 12 subindicators of Main Values $(i=1, \ldots, 12)$ and 15 subindicators $(j=1, \ldots, 15)$ of Additional Values.

Based on the assessment results, a matrix of Main (X axes) and Additional Values ( $\mathrm{Y}$ axes) is created. The matrix is divided into nine fields represented with $\mathrm{Z}(\mathrm{i}, \mathrm{j}),(\mathrm{i}, \mathrm{j}=1,2,3)$. 
Depending on the final score, each geosite will fit into a certain field. For example, if a geosite's Main Values are 7 and additional are 4 , the geosite will fit into the $Z_{21}$ field which clearly indicates a medium level of Main and a low level of Additional Values.

While in GAM all grades for each subindicator are given by experts M-GAM, focuses not only on the expert's opinion but also on the opinion of visitors and tourists regarding the importance of each indicator in the assessment process.

Visitor inclusion in the assessment process is done through a survey where each respondent is asked to rate the importance ( $I m$ ) of all 27 subindicators (from 0.00 to 1.00 ) in the M-GAM model (Table 1). The importance factor $(I m)$ gives visitors the opportunity to express their opinion about each subindicator in the model and how important it is for them when choosing and deciding between several geosites that they wish to visit. After each respondent rates the importance of every subindicator, the average value of each subindicator is calculated as the final value of that subindicator. Afterwards, the value of the importance factor (Im) is multiplied with the value that was given by experts (also from 0.00 to 1.00 ) who evaluate the current state and value of subindicators (Table 1).

Table 1. The structure of Geosite Assessment Model (GAM)

\begin{tabular}{|l|l|}
\hline \multicolumn{2}{|l|}{ Indicators/Subindicators } \\
\hline Main values (MV) & Nescription \\
\hline Scientific/Educational value (VSE) \\
\hline 1. Rarity & $\begin{array}{l}\text { Didactic and exemplary characteristics of the site due to its own } \\
\text { quality and general configuration }\end{array}$ \\
\hline 2. Representativeness & $\begin{array}{l}\text { Number of written papers in acknowledged journals, thesis, } \\
\text { presentations and other publications }\end{array}$ \\
\hline $\begin{array}{l}\text { 3. Knowledge on geoscientific } \\
\text { issues }\end{array}$ & $\begin{array}{l}\text { Level of interpretive possibilities on geological and } \\
\text { geomorphologic processes, phenomena and shapes and level of } \\
\text { scientific knowledge }\end{array}$ \\
\hline 4. Level of interpretation & $\begin{array}{l}\text { Number of viewpoints accessible by a pedestrian pathway. Each } \\
\text { must present a particular angle of view and be situated less than } \\
\text { 1 km from the site. }\end{array}$ \\
\hline Scenic/Aesthetic (VSA) & $\begin{array}{l}\text { Whole surface of the site. Each site is considered in quantitative } \\
\text { relation to other sites }\end{array}$ \\
\hline 5. Viewpoints & $\begin{array}{l}\text { Panoramic view quality, presence of water and vegetation, } \\
\text { absence of human-induced deterioration, vicinity of urban area, } \\
\text { etc. }\end{array}$ \\
\hline 6. Surface & $\begin{array}{l}\text { Level of contrast to the nature, contrast of colors, appearance of } \\
\text { shapes, etc. }\end{array}$ \\
\hline $\begin{array}{l}\text { 7. Surrounding landscape and } \\
\text { nature }\end{array}$ & $\begin{array}{l}\text { Protection by local or regional groups, national government, } \\
\text { international organizations, etc. }\end{array}$ \\
\hline 8. Environmental fitting of sites \\
\hline Protection (VPr)
\end{tabular}




\begin{tabular}{|c|c|}
\hline 11. Vulnerability & Vulnerability level of geosite \\
\hline 12. Suitable number of visitors & $\begin{array}{l}\text { Proposed number of visitors on the site at the same time, } \\
\text { according to surface area, vulnerability and current state of } \\
\text { geosite }\end{array}$ \\
\hline \multicolumn{2}{|l|}{ Additional values (AV) } \\
\hline \multicolumn{2}{|l|}{ Functional values (VFn) } \\
\hline 13. Accessibility & Possibilities of approaching to the site \\
\hline 14. Additional natural values & $\begin{array}{l}\text { Number of additional natural values in the radius of } 5 \mathrm{~km} \\
\text { (geosites also included) }\end{array}$ \\
\hline $\begin{array}{l}\text { 15. Additional anthropogenic } \\
\text { values }\end{array}$ & $\begin{array}{l}\text { Number of additional anthropogenic values in the radius of } 5 \\
\mathrm{~km}\end{array}$ \\
\hline 16. Vicinity of emissive centers & Closeness of emissive centers \\
\hline $\begin{array}{l}\text { 17. Vicinity of important road } \\
\text { network }\end{array}$ & Closeness of important road networks in the radius of $20 \mathrm{~km}$ \\
\hline 18. Additional functional values & Parking lots, gas stations, mechanics, etc. \\
\hline \multicolumn{2}{|l|}{ Touristic values (VTr) } \\
\hline 19. Promotion & Level and number of promotional resources \\
\hline 20. Organized visits & Annual number of organized visits to the geosite \\
\hline 21. Vicinity of visitors centers & Closeness of visitor center to the geosite \\
\hline 22. Interpretative panels & $\begin{array}{l}\text { Interpretative characteristics of text and graphics, material } \\
\text { quality, size, fitting to surroundings, etc. }\end{array}$ \\
\hline 23. Number of visitors & Annual number of visitors \\
\hline 24. Tourism infrastructure & $\begin{array}{l}\text { Level of additional infrastructure for tourist (pedestrian } \\
\text { pathways, resting places, garbage cans, toilets etc.) }\end{array}$ \\
\hline 25. Tour guide service & $\begin{array}{l}\text { If exists, expertise level, knowledge of foreign language(s), } \\
\text { interpretative skills, etc. }\end{array}$ \\
\hline 26. Hostelry service & Hostelry service close to geosite \\
\hline 27. Restaurant service & Restaurant service close to geosite \\
\hline
\end{tabular}

\begin{tabular}{|c|c|c|c|c|c|}
\hline \multicolumn{6}{|c|}{ Grades (0.00-1.00) } \\
\hline & 0.00 & 0.25 & 0.50 & 0.75 & 1.00 \\
\hline 1. & Common & Regional & National & International & $\begin{array}{l}\text { The only } \\
\text { occurence }\end{array}$ \\
\hline 2. & None & Low & Moderate & High & Utmost \\
\hline 3. & None & $\begin{array}{l}\text { Local } \\
\text { publications }\end{array}$ & $\begin{array}{l}\text { Regional } \\
\text { publications }\end{array}$ & $\begin{array}{l}\text { National } \\
\text { publications }\end{array}$ & $\begin{array}{l}\text { International } \\
\text { publications }\end{array}$ \\
\hline 4. & None & $\begin{array}{l}\text { Moderate level } \\
\text { of processes but } \\
\text { hard to explain } \\
\text { to non experts }\end{array}$ & $\begin{array}{l}\text { Good example } \\
\text { of processes but } \\
\text { hard to explain } \\
\text { to non experts }\end{array}$ & $\begin{array}{l}\text { Moderate level } \\
\text { of processes but } \\
\text { easy to explain } \\
\text { to common } \\
\text { visitor }\end{array}$ & $\begin{array}{l}\text { Good example } \\
\text { of processes and } \\
\text { easy to explain } \\
\text { to common } \\
\text { visitor }\end{array}$ \\
\hline 5. & None & 1 & 2 to 3 & 4 to 6 & More than 6 \\
\hline
\end{tabular}




\begin{tabular}{|c|c|c|c|c|c|}
\hline 6. & Small & - & Medium & - & Large \\
\hline 7. & - & Low & Medium & High & Utmost \\
\hline 8. & Unfitting & - & Neutral & - & Fitting \\
\hline 9. & $\begin{array}{l}\text { Totally damaged } \\
\text { (as a result } \\
\text { of human } \\
\text { activities) }\end{array}$ & $\begin{array}{l}\text { Highly damaged } \\
\text { (as a result } \\
\text { of natural } \\
\text { processes) }\end{array}$ & $\begin{array}{l}\text { Medium } \\
\text { damaged } \\
\text { (with essential } \\
\text { geomorphologic } \\
\text { features } \\
\text { preserved) }\end{array}$ & $\begin{array}{l}\text { Slightly } \\
\text { damaged }\end{array}$ & No damage \\
\hline 10. & None & Local & Regional & National & International \\
\hline 11. & $\begin{array}{l}\text { Irreversible } \\
\text { (with possibility } \\
\text { of total loss) }\end{array}$ & $\begin{array}{l}\text { High (could be } \\
\text { easily damaged) }\end{array}$ & $\begin{array}{l}\text { Medium (could } \\
\text { be damaged } \\
\text { by natural } \\
\text { processes } \\
\text { or human } \\
\text { activities) }\end{array}$ & $\begin{array}{l}\text { Low (could } \\
\text { be damaged } \\
\text { only by human } \\
\text { activities) }\end{array}$ & None \\
\hline 12. & 0 & 0 to 10 & 10 to 20 & 20 to 50 & More than 50 \\
\hline 13. & Inaccessible & $\begin{array}{l}\text { Low (on foot } \\
\text { with special } \\
\text { equipment and } \\
\text { expert guide } \\
\text { tours) }\end{array}$ & $\begin{array}{l}\text { Medium (by } \\
\text { bicycle and } \\
\text { other means of } \\
\text { man-powered } \\
\text { transport) }\end{array}$ & High (by car) & Utmost (by bus) \\
\hline 14. & None & 1 & 2 to 3 & 4 to 6 & More than 6 \\
\hline 15. & None & 1 & 2 to 3 & 4 to 6 & More than 6 \\
\hline 16. & $\begin{array}{l}\text { More than } 100 \\
\mathrm{~km}\end{array}$ & 100 to $50 \mathrm{~km}$ & 50 to $25 \mathrm{~km}$ & 25 to $5 \mathrm{~km}$ & Less than $5 \mathrm{~km}$ \\
\hline 17. & None & Local & Regional & National & International \\
\hline 18. & None & Low & Medium & High & Utmost \\
\hline 19. & None & Local & Regional & National & International \\
\hline 20. & None & $\begin{array}{l}\text { Less than } 12 \text { per } \\
\text { year }\end{array}$ & $\begin{array}{l}12 \text { to } 24 \text { per } \\
\text { year }\end{array}$ & $\begin{array}{l}24 \text { to } 48 \text { per } \\
\text { year }\end{array}$ & $\begin{array}{l}\text { More than } 48 \\
\text { year per }\end{array}$ \\
\hline 21. & $\begin{array}{l}\text { More than } 50 \\
\text { km }\end{array}$ & 50 to $20 \mathrm{~km}$ & 20 to $5 \mathrm{~km}$ & 5 to $1 \mathrm{~km}$ & Less than $1 \mathrm{~km}$ \\
\hline 22. & None & Low quality & Medium quality & High quality & Utmost quality \\
\hline 23. & None & $\begin{array}{l}\text { Low (less than } \\
5000)\end{array}$ & $\begin{array}{l}\text { Medium (5001 } \\
\text { to } 10000)\end{array}$ & $\begin{array}{l}\text { High (10 } 001 \text { to } \\
100000)\end{array}$ & $\begin{array}{l}\text { Utmost (more } \\
\text { than } 100000 \text { ) }\end{array}$ \\
\hline 24. & None & Low & Medium & High & Utmost \\
\hline 25. & None & Low & Medium & High & Utmost \\
\hline 26. & $\begin{array}{l}\text { More than } 50 \\
\text { km }\end{array}$ & $25-50 \mathrm{~km}$ & $10-25$ km & $5-10 \mathrm{~km}$ & Less than $5 \mathrm{~km}$ \\
\hline 27. & $\begin{array}{l}\text { More than } 25 \\
\mathrm{~km}\end{array}$ & $10-25 \mathrm{~km}$ & $10-5 \mathrm{~km}$ & $1-5 \mathrm{~km}$ & Less than $1 \mathrm{~km}$ \\
\hline
\end{tabular}


This is done for each subindicator in the model after which the values are added up according to M-GAM equation but this time with more objective and accurate final results due to the addition of the importance factor (Im). This parameter is determined by visitors who rate it in the same way as experts rate the subindicators for Main and Additional Values by giving them one of the following numerical values: $0.00,0.25,0.50,0.75$ and 1.00, marked as points. The importance factor $(I m)$ is defined, as:

$$
I m=\frac{\sum_{k-1}^{K} I v_{k}}{K}
$$

Where $I v_{k}$ is the assessment/score of one visitor for each subindicator and $\mathrm{K}$ is the total number of visitors. Note that the Im parameter can have any value in the range from 0.00 to 1.00 .

Finally, the modified GAM equation is defined and presented in the following form:

$$
\begin{gathered}
M-G A M=M V+A V \\
M V=\sum_{i=1}^{n} I m_{i} \cdot M V_{i} \\
A V=\sum_{i=1}^{n} I m_{j} \cdot A V_{j}
\end{gathered}
$$

As it can be seen from the $M-G A M$ equation, the value of the importance factor (Im), which is rated by visitors (for each subindicator separately) is multiplied with the value given by experts (also separately for each subindicator). This is done for each subindicator in the model.

In their research about different geotouristic segments, Božić and Tomić (2015) conducted a survey and calculated the importance factor for each subindicator in the MGAM model. Therefore, the values of the importance factor in this paper have been adopted from the mentioned paper.

\section{RESULTS AND DISCUSSION}

The main goal of this paper was to compare two similar geosites, Devil's Town in Serbia $\left(\mathrm{GS}_{1}\right)$ and Bryce Canyon in USA $\left(\mathrm{GS}_{2}\right)$ by using the M-GAM model and to determine the advantages and disadvantages of the analyzed geosites in order to detect the areas where there is room for improvement. These geosites were compared and analyzed upon the above mentioned methodology (M-GAM). The values of main and additional subindicators are presented in table 2 . The final results are presented in table 3 and figure 3. 
Table 2. Values given by experts and visitors for each subindicator in the M-GAM model

\begin{tabular}{|c|c|c|c|c|c|}
\hline \multirow{2}{*}{$\begin{array}{l}\text { Main Indicators / Subindicators } \\
\text { I Scientific/Educational values (VSE) }\end{array}$} & \multicolumn{2}{|c|}{$\begin{array}{l}\text { Values given by } \\
\text { experts }(0-1)\end{array}$} & \multirow[t]{2}{*}{ Im } & \multicolumn{2}{|c|}{ Total value } \\
\hline & $\mathrm{GS}_{1}{ }^{*}$ & $\mathrm{GS}_{2}^{* *}$ & & $\mathrm{GS}_{1}$ & $\mathrm{GS}_{2}$ \\
\hline 1. Rarity & 0.75 & 1.00 & 0.89 & 0.67 & 0.89 \\
\hline 2. Representativeness & 1.00 & 1.00 & 0.79 & 0.79 & 0.79 \\
\hline 3. Knowledge on geoscientific issues & 0.50 & 0.75 & 0.45 & 0.22 & 0.34 \\
\hline 4. Level of interpretation & 0.50 & 0.75 & 0.85 & 0.43 & 0.64 \\
\hline \multicolumn{6}{|l|}{ II Scenic/Aesthetic (VSA) } \\
\hline 5. Viewpoints & 0.75 & 1.00 & 0.79 & 0.59 & 0.79 \\
\hline 6. Surface & 0.75 & 1.00 & 0.54 & 0.41 & 0.54 \\
\hline 7. Surrounding landscape and nature & 0.75 & 1.00 & 0.95 & 0.71 & 0.95 \\
\hline 8. Environmental fitting of sites & 0.75 & 0.75 & 0.68 & 0.51 & 0.51 \\
\hline \multicolumn{6}{|l|}{ III Protection (VPr) } \\
\hline 9. Current condition & 0.75 & 1.00 & 0.83 & 0.62 & 0.83 \\
\hline 10. Protection level & 0.75 & 0.75 & 0.76 & 0.57 & 0.57 \\
\hline 11. Vulnerability & 0.50 & 0.75 & 0.58 & 0.29 & 0.44 \\
\hline 12. Suitable number of visitors & 0.75 & 1.00 & 0.42 & 0.32 & 0.42 \\
\hline \multicolumn{6}{|l|}{ IV Functional values (VFn) } \\
\hline 13. Accessibility & 0.75 & 0.25 & 0.75 & 0.56 & 0.19 \\
\hline 14. Additional natural values & 0.25 & 0.75 & 0.71 & 0.18 & 0.53 \\
\hline 15. Additional anthropogenic values & 0.25 & 0.25 & 0.70 & 0.18 & 0.18 \\
\hline 16. Vicinity of emissive centers & 0.25 & 0.25 & 0.48 & 0.12 & 0.12 \\
\hline 17. Vicinity of important road network & 0.75 & 0.25 & 0.62 & 0.47 & 0.16 \\
\hline 18. Additional functional values & 0.25 & 0.25 & 0.59 & 0.15 & 0.15 \\
\hline \multicolumn{6}{|l|}{ V Touristic values (VTr) } \\
\hline 19. Promotion & 1.00 & 1.00 & 0.85 & 0.85 & 0.85 \\
\hline 20. Organized visits & 1.00 & 1.00 & 0.56 & 0.56 & 0.56 \\
\hline 21. Vicinity of visitors centers & 0.25 & 0.25 & 0.87 & 0.22 & 0.22 \\
\hline 22. Interpretative panels & 0.00 & 0.25 & 0.81 & 0.00 & 0.20 \\
\hline 23. Number of visitors & 0.75 & 1.00 & 0.43 & 0.32 & 0.43 \\
\hline 24. Tourism infrastructure & 0.75 & 1.00 & 0.73 & 0.55 & 0.73 \\
\hline 25. Tour guide service & 0.50 & 1.00 & 0.87 & 0.44 & 0.87 \\
\hline 26. Hostelry service & 0.50 & 0.50 & 0.73 & 0.37 & 0.37 \\
\hline 27. Restaurant service & 0.75 & 0.50 & 0.78 & 0.59 & 0.39 \\
\hline
\end{tabular}

${ }^{*} G S_{1}$ - Devil's Town, ** $\mathrm{CS}_{2}$ - Bryce Canyon 
Table 3. Overall ranking of the analyzed geosites by using M-GAM

\begin{tabular}{|l|c|c|c|c|c|}
\hline \multirow{2}{*}{ Geosite } & \multicolumn{2}{|c|}{ Main values } & \multicolumn{2}{c|}{ Additional values } & \multirow{2}{*}{ Field } \\
\cline { 2 - 5 } & VSE+VSA+VPr & $\Sigma$ & VFn+VTr & $\Sigma$ & \\
\hline Devil's Town $-\mathrm{CS}_{1}$ & $2,11+2,22+1,80$ & 6,13 & $1,66+3,90$ & 5,56 & $\mathrm{Z} 22$ \\
\hline Bryce Canyon $-\mathrm{GS}_{2}$ & $2,66+2,79+2,26$ & 7,71 & $1,33+4,62$ & 5,95 & $\mathrm{Z} 22$ \\
\hline
\end{tabular}

The main values are significantly higher for Bryce Canyon (7.71) than for Devil's Town (6.13). According to the obtained results the biggest difference occurs with scientific values. Bryce Canyon (2.68) has higher values than Devil's Town (2.11). One of the reasons for this is that Devil's Town geosite is less explored by the scientific community than Bryce Canyon. It also has lower values for the subindicators rarity and level of interpretation. This could be explained by the fact that there is a similar site in the nearby country of Romania as well as that geosites and geotourism still remain largely unexplored in Serbia. Very few resources are directed towards the development of geotourism and interpretive facilities.

A major difference can also be noticed when it comes to aesthetic values of the analyzed sites. Surface area and number of viewpoints are what gives Bryce Canyon an advantage in relation to Devil's Town.

If we look at protection values, we can clearly see that both sites have the same protection level. However, due to the geological composition and geomorphological features, Devil's Town is more vulnerable. The carrying capacity is also significantly higher in the case of Bryce Canyon.

If we take a look at additional values, we can see that Bryce Canyon is slightly higher rated (5.95) than Devil's Town (5.56). Functional values such as road networks and accessibility are higher in the case of Devil's Town, However, additional natural values are higher in the case of Bryce Canyon since it is located in a National Park.

The main difference between the analyzed geosites is in their tourist value. Table 3 shows that Bryce Canyon has higher tourist value (4.62) than Devil's Town (3.90). Both geosites are often present in the media and thus have high grades for the subindicator promotion which was also rated as one of the most important for tourists. However, when it comes to tourism infrastructure, interpretation and guide service, Devil's Town falls behind. Interpretive panels still do not exist at the site. Additional visitor infrastructure (walking paths, resting places, bins, toilets etc.) is currently at the medium level. The tour guide service, which is one of the most important subindicators according to visitors, is still at a lower level of quality. Better trained guides who speak several languages and possess good interpretive skills, preferably with a background in geology are needed in the future. These necessities are available at Bryce Canyon and are present at a much higher level. Besides this, the vicinity of visitor centers is more than $5 \mathrm{~km}$ while hostelry services are available $10-20 \mathrm{~km}$ further away from the site. This represents a significant barrier for tourism development. All of these facts point to a lack of adequate planning and management of tourism at these destinations which has resulted in a small number of tourists at Devil's Town. One of the main problems when it comes to Devil's Town is its location. It is located 
in the part of the country which is mainly uninhabited, more than $100 \mathrm{~km}$ far from emissive tourist centers and main roads.

Comparing the final results for the analyzed geosites, one can clearly see the differences in their main and additional values, as well as their position in the M-GAM matrix (Figure 3).

Finally, we can conclude that the most attention in the future should be focused on additional values. If we look at the values of the importance factors we will see that the most important elements for visitors are tour guide service, visitor centers and promotional activities. Given the importance that visitors attach to these elements, it is necessary to seriously deal with these issues in the future. One of the main drawbacks is certainly a good quality tour guide service. More professional and educated guides are needed, preferably from a geological or any related profession from the field of geosciences. Also, more attention should be focused towards promotional activities abroad

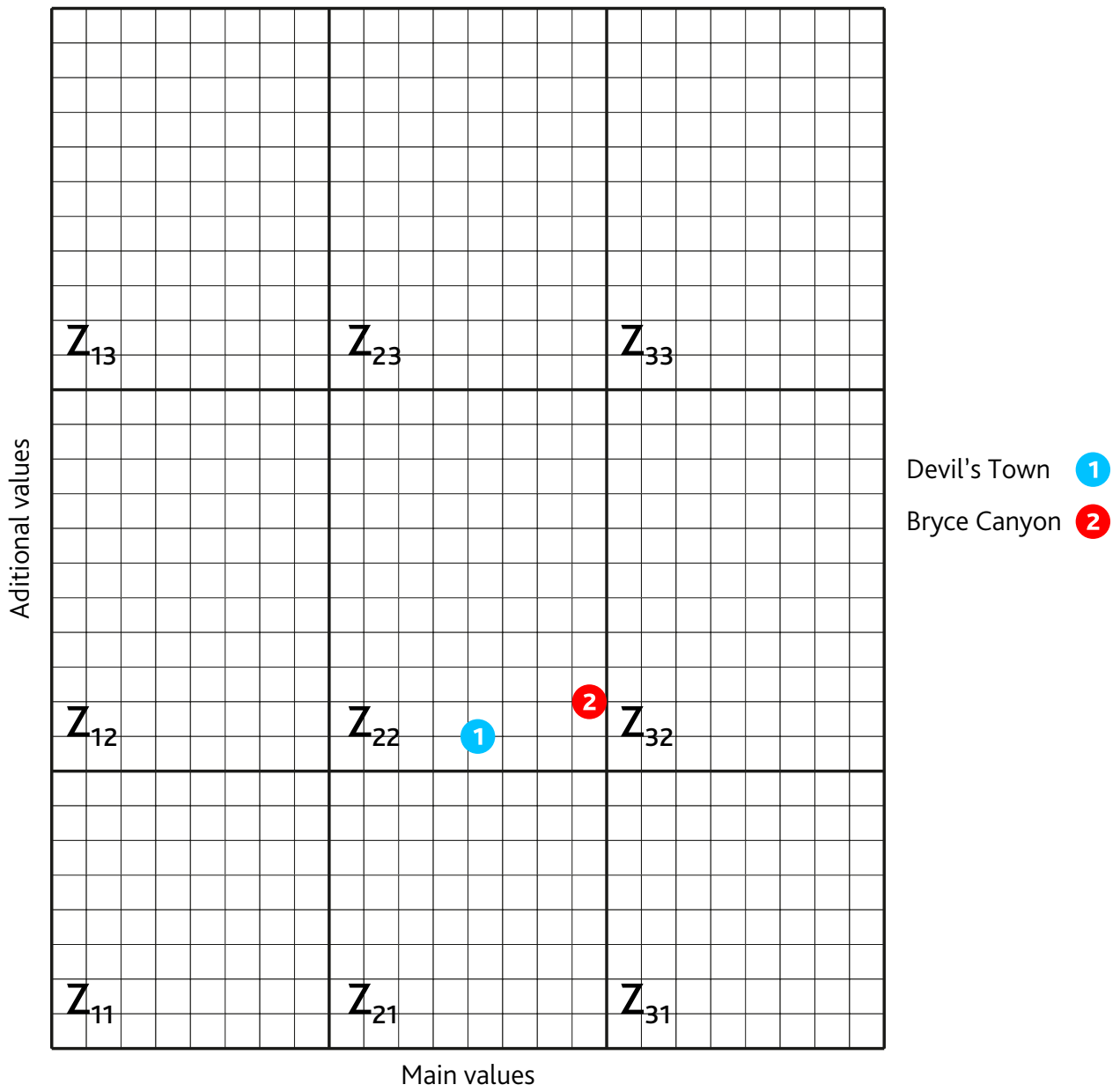

Figure 3. Position of the assessed geosites in the M-GAM matrix 
but as well as within our borders. Besides these elements, tourists also highly value the presence of good quality interpretive panels, tourist infrastructure and hostelry and restaurant services. The first two elements do not require larger investments and should be the primary focus in the future as they can be provided much more easily than hostelry and restaurant services.

\section{CONCLUSION}

The main objective of this study was to compare two similar geosites in two countries with different level of tourism development, Serbia and USA. From our results we can conclude that both analyzed geosites have great tourism potential mainly due to their aesthetic value. By applying the M-GAM model we revealed the advantages and disadvantages of both geosites. Our results show which areas primarily require improvement for further geotourism development. According to our results, Devil's Town needs to be better explored by the scientific community in order to achieve higher values in the M-GAM matrix and to provide a good basis for further geotourism development. As it is the case with most geosites in Serbia, this one also has plenty of room for improvement when it comes to functional and tourist values. Examples such as Bryce Canyon are excellent for showing how a geosite should be managed and how some crucial elements should be improved. These elements are mainly connected to promotional activities, tour guide service and interpretive panels which need to be significantly improved in the future. By doing so, this geosite can attract a much larger number of visitors which would positively reflect the local economy and development.

\section{REFERENCES}

Božić, S., Tomić, N. (2015). Canyons and gorges as potential geotourism destinations in Serbia: comparative analysis from two perspectives - general geotourists and pure geotourists. Open Geosciences, 7, 531-546

Bruschi, V.M., Cendrero, A. (2005). Geosite evaluation. Can we measure intangible values? Il Quaternario, 18(1), 293-306.

Collison, F.M., Poe, K. (2013). Astronomical Tourism": The Astronomy and Dark Sky Program at Bryce Canyon National Park. Tourism Management Perspectives, 7, 1-15.

Coratza, P., Giusti, C. (2005). Methodological proposal for the assessment of the scientific qualityof geomorphosites. Il Quaternario, 18(1), 307-313.

Djurović, P., Mijović, D. (2006). Geoheritage of Serbia-Representative of its total geodiversity. Zbornik Radova Geografskog Fakulteta u Beogradu, 54, 5-18.

Hose, T.A. (1997). Geotourism - selling the earth to Europe. In: Engineering geology and the environment (Marinos P G, Koukis G C, Tsiambaos G C and Stournaras G C, Eds.). Rotterdam: A.A Balkema pp. 2955-2960.

Hose, T.A. (2003). Geotourism in England: A Two-Region Case Study Analysis. Unpublished $\mathrm{PhD}$ thesis, University of Birmingham, Birmingham, UK 
Hose, T.A. (2007). Geotourism in Almeria province, southeast Spain, Tourism, 55, 259276.

Hose, T.A. (2008). Towards a history of Geotourism: definitions, antecedents and the future. In: The History of Geoconservation, (Burek, C.V. \& Prosser, C.D., Eds.). Geological Society of London, London, UK, pp. 37-60.

Hose, T.A., Vasiljević, Dj.A. (2012). Defining the Nature and Purpose of Modern Geotourism with Particular Reference to the United Kingdom and South-East Europe. Geoheritage, 4, 25-43.

Jovanović, A. (2010). Geokonzervacija Đavolje varoši - osnov za razvoj geoturizma. Diplomski rad. Departman za geografiju, turizam i hotelijerstvo, Prirodnomatematički fakultet, Univerzitet u Novom Sadu.

Pereira, P., Pereira, D., Caetano Alves, M.I. (2007). Geomorphosite assessment in Montesinho Natural Park (Portugal). Geographica Helvetica, 62, 150-168.

Pralong, J.P. (2005). A method for assessing the tourist potential and use of geomorphological sites. Géomorphologie. Relief, processes, environnement, 3, 189-196.

Reynard, E. (2004). Geosite. In Encyclopedia of geomorphology (Goudie, A.S., Ed.). London: Routledge.

Reynard, E. (2008). Scientific research and tourist promotion of geomorphological heritage. Geografia fisica e dinamica quaternaria, 31(2), 225-230.

Reynard, E., Fontana. G., Kozlik, L., Scapozza, C. (2007). A method for assessing „scientific" and "additional values" of geomorphosites. Geographica Helvetica, 62(3), 148158.

Serrano, E., González-Trueba, J.J. (2005). Assessment of geomorphosites in natural protected areas: the Picos de Europa National Park (Spain). Géomorphologie. Formes, processus, environnement, 3, 197-208.

Tomić, N. (2011). The potential of Lazar Canyon (Serbia) as a geotourism destination: inventory and evaluation. Geographica Pannonica, 15(3), 103-112.

Tomić, N., Božić, S. (2014). A modified geosite assessment model (M-GAM) and its application on the Lazar Canyon area (Serbia). International Journal of Environmental Research, 8(4), 1041-1052.

White, S., Wakelin-King, G.A. (2014). Earth sciences comparative matrix: a comparative method for geoheritage assessment. Geographical research, 52(2), 168-181.

Zouros, N.C. (2007). Geomorphosite assessment and management in protected areas of Greece. The case of the Lesvos island coastal geomorphosites. Geographica Helvetica, 62, 169-180. 